\title{
THE WOMAN QUESTION IN EGYPT
}

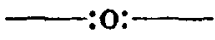

THE minds of Moslem men in Egypt have been in great commotion of late, as to whether women should be veiled and kept in seclusion, or have their veils removed and enjoy the freedom of European women.* A number of articles on both sides of the question have been published in the Moslem press, and the following paragraphs translated from the Arabic will show what agitates the minds of many Moslems. A society of young men has been formed, whose object is to abolish the veil ; recently one of its members went (according to the Mohammedan papers) to a high-class school conducted by nuns, and by pretending to seek the admission of his sister as a pupil, he gained entrance and gave an address on this subject to the girls, much to the dismay of those who conform to traditions and former customs. This ruse was tried in our schools also, but those in charge were too cautious to allow the girls to be examined as to their proficiency in their studies.

The first article which we quote is an extract from a letter written by an Egyptian now studying in England : "Some of the reasons for the advancement of the English nation."

* The effect is evident also in the Legislative assembly ; we learn from one of the English papers that an interesting Bill has lately been submitted to the Legislative assembly. It deals with the age at which girls may legally marry. The proposer of the Bill states that it is a recognised fact that the very low marriage age is responsible for degeneration in Oriental countries and for much of the disease that is prevalent. He suggests that the minimum age at which a girl may marry shall be fixed at sixteen years, calculated according to the Moslem calendar, and proposes that parents who permit their daughters, and guardians who pernit their wards, to marry under that age, shall be made liable to serere penalties, as also the husband who marries a girl under sixteen. This law is to apply to all Egsptians; but it is to be foreseen that it will meet with a certain amount of opposition, although the excellence of its fundanental principles is recognised. 
"For a long time the Egyptian woman has been prevented from partaking of the fruits of education, because of the man's opinion that the enlightenment of the woman's mind is injurious to her morals. Man took from woman her personal freedom, imprisoned her gifts, and denied her education, because he thought only of himself and his excessive love of power. Thus the woman was not allowed to take her important place in society. He would not allow her to be like him, but reproached her with the saying that her mind was weak and that she could not understand things. He did not know that he was responsible for this ignorance and the cause of it. The attention of people to the education of woman and the loosing of the bands of illiteracy was aroused by the late Kassim Bey Amin, who without doubt was the pioneer in the revival of Egyptian women. Since that time there are other thoughtful men trying to improve the condition of women, because they realize that the education of woman is one of the pillars of elevation and advancement, and the first stone in the reviving of nations. The greatest proof of this is the fact that, in some countries, women, if they do not receive more education than men, receive no less.

"I think I owe it to my countrymen to write something about the teaching of women in England in all branches of education, so that public opinion in Egypt may be aroused to learn something of the cause of the elevation of this great nation, from whom we may well copy some of their good ideas."

The writer then goes on to tell about the schools for compulsory education, and says that everyone in England knows how to read and write. The punishments for absence from school are enforced. Then he speaks of schools for the weak-minded, and kindergarten schools for the poor. He also mentions that the children are taught together until they are eight y'ears old, and then the sexes are separated. He speaks of the general and difficult examinations for all classes, when the reward for those who succeed is free education in higher schools, thus enabling the poor to continue their studies. Then he states that the girls may enter the secondary schools, 
commercial schools and universities. He commends the commercial schools for people in the middle classes, and says : "It seems to me that teaching sciences and professions to girls has no danger in it, but a great many advantages. If a girl is wealthy, she finds the knowledge gained an enlightenment and a high enjoyment; in case she becomes poor, she is able to earn her living by the sweat of her brow, instead of giving way to despair like so many in the East; or instead of living by vice, which brings to her and to society everlasting shame."

In a later copy of The Moayyid there is a lengthy article on the "Foundation of the Life of a Nation, or the influence of woman in the elevation of a country." It is translated from an article in a Turkish newspaper, and the writer says: "The most important evidence of a revival and awakening which have resulted from the last war, is our willingness to admit the necessity of improving our social conditions. No one will deny that one of the causes of this great calamity was connected with our general life. All nations must be prepared for war by right living in time of peace, when children can be taught courage and self-reliance (but self-reliance and self-support have been declining from the hearts of the Ottomans for one hundred years or more), for we need energy and force well directed by skill. We have learned to know our standing, and have learned that we must understand our nation's real feelings and the bond that unites us ... We have learned that the nations which think only of physical enjoyments, will fall. Each individual must be willing to make sacrifices, and we must gain national wealth instead of constantly spending our resources. We must have mental strength, and this requires well superintended elementary schools-the most important thing after our own homes. There the wife and mother should reign, and everyone now admits that the East will not be elevated until woman is elevated and restored to the position she once occupied. The fall of Moslem womanhood has been the greatest reason for the fall of the whole nation, and her education and uplift are necessary if the nation is to regain its lost position."

The same paper contains an article appealing to 
Mohammedans to avoid the civilization of the west, which is too full of worthlessness and poison, notwithstanding the writings of Kassim Bey Amin. The article states: "More than twenty learned men have been writing on the same subject, and nothing new can be advanced. Even French and English writers have spoken of the evils resulting from modern civilization and freedom, which have wrought so much evil in family life, as well as tended to decrease the population." In comparing the Egyptian woman of to-day and the woman of ten years ago, he says, "The modern woman has lost all manners, has no regard for morals, and her only thought is to be dressed in the latest fashion, whether her house is cared for or not, and whether her children are trained or allowed to run wild; whereas the former style of woman was the opposite of this. Now will those who are seeking to remove the veil from woman benefit her and others, or what will be the result? We do not deny that Egyptian women are backward and need improvement, and we admit that her want of advancement is one great hindrance to us men; but her uplift will not result from removing the evil. It will have the opposite effect." He then quotes poetry from their learned men of past ages, and aslzs the question: "Is B__'s mind greater than Ghazzali's? Is the blind following of any man the rule of religion? Is the removing of the veil lawful in this Mohammedan religion, or is it wrong? If it is right, where is the place in the book where it is permitted ? Now if it is wrong, are you farther sighted than the Koran, or has modern civilization put a covering over your hearts ?"

A lengthy article in the same paper speaks of women before Mohammedanism and after it. It is a translation of "Polygamy in Islam," by the Seyyid Amir Ali. "The greatest mistake of Christians is their saying that Mohammed was the first one to make polygamy lawful, for we can show that this is untrue. Mohammed found polygamy prevalent, and it remained so. In Persia this was the time of moral degradation, and there was no law regarding plural marriages, the man taking as many wives and concubines as he wished. The early Arabs and 
the Jews had a custom also of marrying on conditions, besides for a certain time, which would have brought disaster to Arabia had not God interposed and sent the Prophet of God to raise the position of women and elevate society generally. Among the Jews, under the law of Moses, the daughter had the place of a servant, and the father could sell her; her brothers could act towards her as they chose after her father's death, and she could not inherit anything from her father unless she had a male child. Among the Arabs she had the position of a possession, and when women became widows they were considered the property of the sons of their husbands. Some sons even burnt their mothers alive. This custom was stopped by the Prophet, as he also stopped the slaying of infants as a sacrifice to idols. Surrounding nations also ill-treated women. At such a time the Prophet came with his reforms and his efforts to enforce his good laws. Anyone who studies can see that the honouring of women is one of the pillars of his reforms. We can prove this from the influence which this teaching had on his successors among the Arabs; in the way they honoured his daughter and loved her, calling her 'The Lady of Light.' This teaching also influenced the women, some of whom were crowned with purity and virtue like Fatimah. Although at first his laws allowed temporary marriages, or marriage by contract, this law was changed in the third year of the Hegira, and he gave them equal rights with men. $\mathrm{He}$ also limited the number of wives, so no one could lawfully take more than four; and he said the four must be treated exactly alike in every way, or the man should marry only one wife. This being an impossibility, proves that Mohammed was in favour of one wife only. However, there may be circumstances in society when polygamy is a necessity and a duty, as, for example, to kecp a poor woman from a life of shame. But when no such circumstances exist and people begin to consider things, there will be no need. The making of laws suitable for the times and the country shows the benefit of the laws made. Some learned people are now looking into the laws so as to make them suit present thought and times. 
The Mohammedans of India are abolishing the custom of polygamy, and now there are ninety-five per cent. who marry only one wife. And in Persia there are only two in a hundred who have more than one wife. We have great hope that the learned men will meet in a religious conference and decide upon a rule which will put down polygamy."

Another writer takes the position that woman in Egypt has no right to have her veil removed, and that she should not take part with men in earning a living. "Many of those who read articles advising these reforms do not know that these arrows are aimed at their holy religion, which in God's sight is a great thing. The Koran has not been silent as to the position and duties of women, and it states the pathway to the elevation of the race. The way to preserve society from evil is to keep women veiled. Would you wish them to copy the crimping of hair, the fancy hairdressing of Westerners, with their painted eye-brows, who flirt with men? If our women learn all this, will they make happy wives ? Listen to advice, and flee from such things as steal away religion. Does not your Lord say-" (and then follow quotations from the Koran instructing women to cover themselves, and a story regarding Mohammed's command to one of his wives, that she must cover herself before a blind man, for even if he could not see her, she could see him. "The covering is necessary, especially in these days when the waves of evil are breaking over us and the tempests of temptation. May God reform the Moslem nation and give it divine guidance."

Another writer, a doctor of laws, says, "There is no distinct order in the Koran that women should be veiled, that they should not see or mix with men, or go about with uncovered faces. The canon law only orders women not to exhibit their ornaments publicly. The habit of wearing a veil originated with the wealthy, and was soon given religious sanction. The peasant women and those of the poorer classes in the towns do not wear veils. They go to the markets, receive their husband's friends at home, help men in their work, and enjoy great liberty inside and outside their houses, and yet no one 
criticises them or finds these habits improper, nor considers them less chaste than others. Blind jealousy, suspicion of one's friends, want of confidence in women, the belief that they have weak wills-these are the reasons which have induced the rich to deprive their women of liberty."

The most radical attack, however, on the old orthodox view of the rights of women, appeared recently in $E l$ Geridah, from the pen of a Moslem student in London, Tewfik Diab. He asks why women should be veiled at all! "Is it because the Mohammedan religion makes the veil a necessity? If so, why do you believe one part of your religion and disbelieve another? Why obey what is very obscurely laid down, and disregard doctrines that are definite and clear? Why not whip the drunkard and the man who neglects his prayers; why not cut off the arm of the thief, and stone the adulterer and the adulteress? (as is laid down in the Koran). Do you really veil your women in order to guard your honour? Are you really afraid that if your womenfolk leave home unveiled their passions will get the better of them, and they will lose control over themselves? Do you think that a chastity that can only be maintained in a prison is worth much ? Do you believe that honour which can only be protected by a rag on the face is an honour preserved? Does a cage turn a lioness into an ewe ? Or does the devil become an angel by wearing a veil ?"

And closes his protest by an outspoken appeal : "You fill the world, you despots, with your cries and your wails for your robbed liberty, and for your vanquished nation, shouting out that freedom is a natural right of man. But, when your conquerors look at you and see that one of your arms is extended to them with prayer and supplication for your freedom and the dustour, and that, with the other, you press upon your daughter, wife, sister, and mother with a palm of flint and fingers of iron; when they see all that, no wonder they laugh at you, and scorn you; for they know that your clamouring after freedom and your tears for the dustour are only a mockery."

Cairo, Egypt.

ANNa Y. Thompson. 